\title{
Analysis of Supporting Components for Quality Standards in Teacher Education and Vocational Training
}

\author{
Suharni, Djoko Laras Budyo Taruno, Moh. Khairudin \\ Universitas Negeri Yogyakarta \\ Yogyakarta, Indonesia \\ suharni2303@gmail.com
}

\begin{abstract}
The purpose of this study is to describe the components of the standard quality control of what is needed in education and vocational training to support the qualified education. This study uses a qualitative approach. Data were collected through three techniques namely interview techniques, questionnaires and observations. The study was conducted in P4TK Bandung. The results of this study is to optimize all components Teacher Training in meeting the Standard for the implementation of the training, so that the training followed would acquire goals as planned is a competence that should be maintained. After attending the training, teachers can implement the materials they got, so that when they return to the school they will improve and develop teaching and learning process, a competence that should be maintained. The management Education and Training requires Human Resources (adult learning, Professional Teachers, development of teacher professionalism), the Vocational Training Management and quality control. In order to guarantee the success of the training also require activities such as: Planning, organizing, actuating and Controlling. The implementation of Training requires quality control standards (Plan, Do, Check, Action) in order to achieve effective and efficient activities.
\end{abstract}

Keywords-Education and Training Management, Standard quality, Vocational Teacher

\section{INTRODUCTION}

The creation process and outcome of the qualified education is strongly influenced by a teacher. Several efforts to improve the quality and professionalism of teachers will improve the education system. Teachers are the most fundamental element, in the formation of the Human Resourcess (HR) at school. The education process is said to be successful if it can bring the majority of learners actively, physically, mentally, and socially in the learning process becoming a passion, enthusiasm and confidence. A teacher's personality is formed from the experience of teaching time and will get the basics of teacher training to become a teacher [1]. The educational outcomes will be successful if the given learning can change the behavior of learners towards a better mastery of competencies indicated by the aspect of knowledge, skills, attitudes, and values possessed.

Teachers in vocational secondary school have productive complex characteristics and the professional requirements such as practical, able to organize and design a teaching and learning process that are relevant to the competencies required by industry or companies. Vocational teachers are expected to constantly update and upgrade the scientific held to the changes that occur in the industry that can be adapted to the school. Otherways, efforts to improve the quality of vocational teachers should be conducted by various programs for increasing teachers professionalism. Increasing the professionalism of teachers is a responsibility of individual teachers in line with changes in the workplace, the development of the science, technology and learners. Teachers can individually improve their competence with their own in the classroom or through communication with colleagues in planning, implementing and evaluating the learning that has been conducted. Teachers should be competent in integrating Information and Comunication Technology with instructional tasks that can facilitate desired changes. Professional development of teachers based on the improvement of pedagogy and knowledge of Information and Comunication Technology. [2]

Self-development is a form of professional development educators who have some form of activities such as training, workshops, technical guidance, some activities of teachers and etc. The strategy in the process of personal and professional development using coaching and mentoring. This method can enrich the broader practices in the development of the individual. [3] The efforts to increase the competence, of teachers through trainings, in Indonesia there are still many problems if they are done conventionally, due to the number of educators who take the training is not proportional to number of providers of training and number of limited trainers. Besides, the educators do not have a lot of time for 
training, because it is not easy for teachers to leave teaching and learning process at schools. External duties make educators unfocused and do not develop their knowledge and skills. Putri Balqis presented teachers' pedagogic competence in planning lessons conducted by preparing a lesson plan, but some teachers do not bring a lesson plan during the learning process so that maximum learning objectives are not achieved; (2) The pedagogic competence of teachers in the learning process is done by understanding and strengthen the understanding on a number of instructional materials contained in the textbook. While in the process of learning, classroom management and punctual control: and (3) pedagogic competence of teachers to improve a student motivation with providing opportunities for students to be actively involved in using information and comunication technological facilities to achieve learning objectives, communicate effectively with learners, and take action to improve the quality of learning [6].

Education and training are strategic management efforts to develop the human resources in order to improve the performances in the educational organizations. Nearly for each big organization has a unit for education and training, but only a vew training units can well organize. A good training is training carried out by following the rules of education and training, in the form of the training cycles. The human resource development can be realized with a good education and training. To make closed bringing a relevant educational programs and community needs, the education should be adapt with required innovations. The training for workers is required at a certain period in order to actualize themselves to the technological developments. The concept of life long education is considered necessary for the world of work. The workers should be train themselves again in the service training, and attend the formal training and non-formal courses. Pedagogical insights and new technology are educational development and training institutions to keep updating and innovating education programs. It requires teachers to demonstrate innovative behavior [4]. The National Education Standards are the minimum criterias regarding to educational system in the entire territory of the Republic of Indonesia. The National Education Standards consist of eight standards that must be possessed and fulfilled by the organizers and or the units of education in Indonesia. These Eight National Standards are graduate Competency Standards, Content Standards, Process Standard, Education Standards and Personnel, Infrastructure Standards, Management Standards, Financing Education Standards and Assessment Standards of Education. The National education qualities can be realized with the planning, execution, and monitoring the function of the National Education Standards. The Purpose of National
Education Standards ensures quality of national education in the context of national lives and forms the characters and civilization of the nation's dignity. The National Education Standards are improved based on the plans, target, and sustainable in accordance with the demands for changes in the local, national, and global spocer.

The quality of vocational training of teachers for vocational education due to continuously improved the process of vocational training experts, the emergence of new techniques and technology training, and changes in social and economic situation in Indonesia, the emergence of innovation of new, high-tech development, changes in legislative basis, the increase in the requirements for the level and efficiency expert training [8]. The continuous improvement of any organisation is possible by following PDCA cycle. With the internal quality assurance activities of the organizers of training can know the state of the on-going quality management, and can determine the quality system, so it can immediately make repairs before arising problems. Application of quality control through internal quality assurance activities is indispensable in the process of continuous improvement [5]. However internal quality assurance does not necessarily have to wait until the first accredited training institution, because this activity can also be implemented on every operator training that is responsive for improving quality of education and training. Based on the foregoing, in each of education and training, necessary activities can give quality assurance against any process of education and training.

Education and vocational training is basically a form of activity in human resource development programs (personal development). The development does not only activities whose objective was the improvement and growth capabilities, attitude, skills, and knowledge-forming character. Education and vocational training teachers are now not in accordance with the needs of an educator. Components of the standard quality control of what is needed in education and vocational training to support quality education. One of the activities in order to create quality standards is to implement appropriate quality control system, have clear objectives and stages, as well as providing innovation in prevention and resolution of problems.

\section{METHODS}

This study uses a qualitative approach. Data were collected through three techniques namely interview techniques, questionnaires and observations involving training managers, facilitators and participants of the Training. Questionnaires were distributed to the 15 respondents who carried out vocational teacher education and training in P4TK Bandung. 
The instruments of this study are questionnaires data which were divided in two parts, namely the management of vocational training and Quality Control. Descriptive analysis techniques used the average score that is used to obtain an overview of the components of education management and optimal training and know standard components of Quality Control required.

\section{RESULTS AND DISCUSSION}

The duties and responsibilities of a teacher, will be correctly and seriously includes preparing a lesson plan, organizing, controlling, guiding, nurturing, and being responsible for the relevants on-going learning process; it will be efficient and effective. Professional Teacher has several indicators, namely: (1) teachers can learn to understand the characteristics of each learner in the classroom; (2) teachers can design the learning activities that are related to others, having regard to the purpose of learning and the learning process of education and training; (3) teachers implement learning activities in accordance with the drafts drawn up completely; (4) teachers conduct assessments with the various types of assessments; (5) teachers design the learning activities to make the power of creativity of the training participants; (6) teachers act in accordance with the norms of the religion believed; (7) Teachers demonstrate the exemplary personals; (8) teachers have a work ethic and high responsibility; (9) teachers have mastering scientific materials that support to subjects; (10) teachers develop the professionalism through the reflective action; (11) teachers communicate with their colleagnes, staff, parents, students and the community; and (12) teachers use information and communication technology functionally.

Figure 1 ilustrates the percentages of teacher proffesionalism.

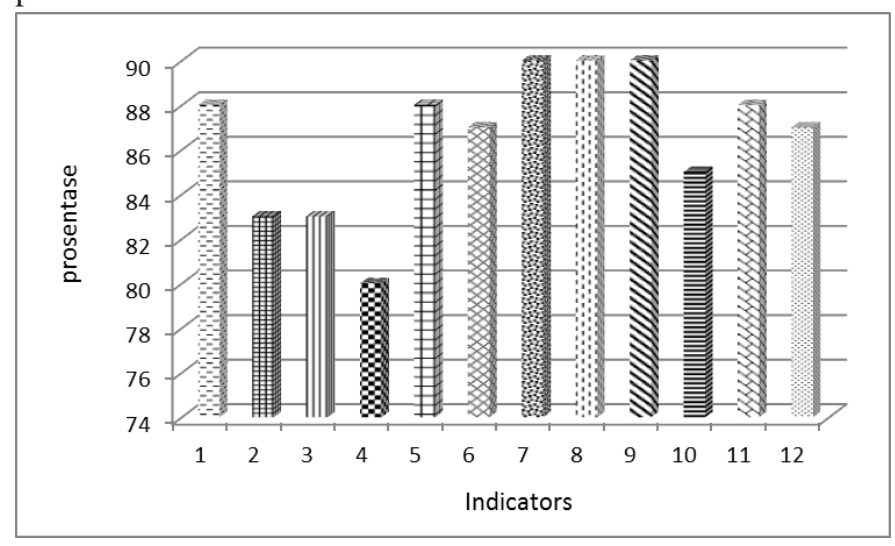

Fig. 1. Profesionalism Teacher

Fig. 1 shows that the indicators should be completely upgraded for an assessment competency such as using various kinds of assessment to conduct it continuously. The indicator stand and improved according to figure 1 is the competence of the learners characteristics, learning activities which raise to the creativity of learners and good communication among students, colleagues, and community. The exemplory persons having the work ethic and high level of responsibility are competences that should be maintained.

The development of the teaching profession should be implemented programmatically and sustainably, through continuous profession development activities, which is one of several activities designed to realize the establishment of a professional teacher. One type of profession development activities is self-development. The Teacher professional development component have several indicators, namely: (1) A teacher periodically attends to functional education and training; (2) A teacher takes the collective activities that teachers do at schools; (3) teachers develop science and technology in writing scientific papers; (4) teachers develop science and technology in writing the scientific papers; (5) teachers develop science and technology in writing modules; (6) teachers develop science and technology in the appropriate technology; (7) teachers develop artwork in the form of instructional medias; and (8) teachers develop science and technology in the modification of learning tools.

The questionnaires results percentage indicator development of teacher professionalism shown in figure 2.

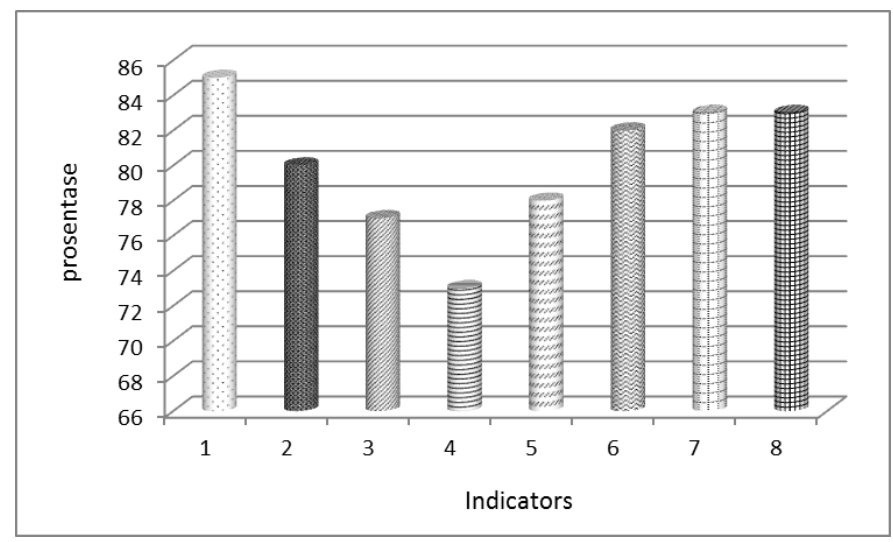

Fig. 2. Development of teacher professionalism

Figure 2 shows that the indicators that need to be improved are the competences of all teachers developing science and technology in writing the scientific papers that training workshops or writing papers need to be implemented. Teachers should enhance skill in the writing module and modifying the learning tools. Teachers should follow functional education and training regularly, so that teachers' knowledge and skill will be updated continously. 
Adult learning is a systematic and sustainable learning process for adults (based on the main characteristics of social roles). The aims of Adult learning are change in knowledge, attitudes, values and skills. Adult learning component includes several indicators, namely: (1) A teacher implement the learning process seriously; (2) teachers carry out the learning process independently; (3) teachers implement the learning process for maturity; (4) teachers carry out the learning process based on the principles of adult learning; (5) Teachers develop the principle of continuing education; (6) teachers implement the learning process refer to the demands of the development of science and technology; (7) teachers carry out the development process in terms of structural changes in school assignments; and (8) teachers implement the learning process based on problem-centered orientation; teachers develop the learning process as education and training. Based on questionnaires results prosentage of component the adult learning shown in figure 3.

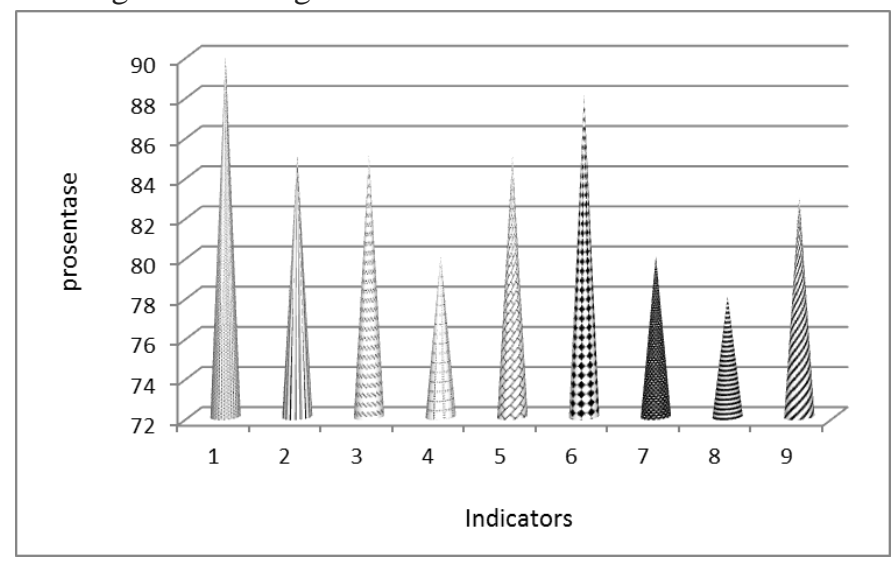

Fig. 3. Adult learning

Figure 3 shows that the indicator teacher should be improved in competences to implement the problem-centered orientation process, so learning process can be more interesting and challenging to solve a problem. The teachers' personal maturity should be improved seriously. The teacher develop the principle of continuing education training, so that the science and materials will continue being updated. Teachers' competence to develop the principle of continuing education training should be maintained.

The aims of strategic management education and training is to develop human resources in order to improve the performance of educational organizations. Almost of big organization has a unit of education and training, but not of all the training unit can organize training well. The education and training management components include several indicators, namely: (1) The teachers should implement the reforms of theoretical learning after attending the training; (2) A teacher should reflect them self after participate in the education and training; (3) teachers should implement the innovative teaching after attending the training; (4) The teachers should adapt in the training process; (5) The teachers should utilise the facilities in the training; (6) teachers should implement the motivation when conduct the training; (7) the teachers communicate to the organizers of the training; (8) The teachers should make the participants active in order to be focus to the purpose of the training; (9) teachers should optimize all training components to fulfill the education and training standard; (10) The teachers should provide a feedback to the training organizers; and (11) The teachers should provide improvements to the irregularities that occurred in the training. Figure 4 ilustrates the percentage of Management Education and Vocational Training.

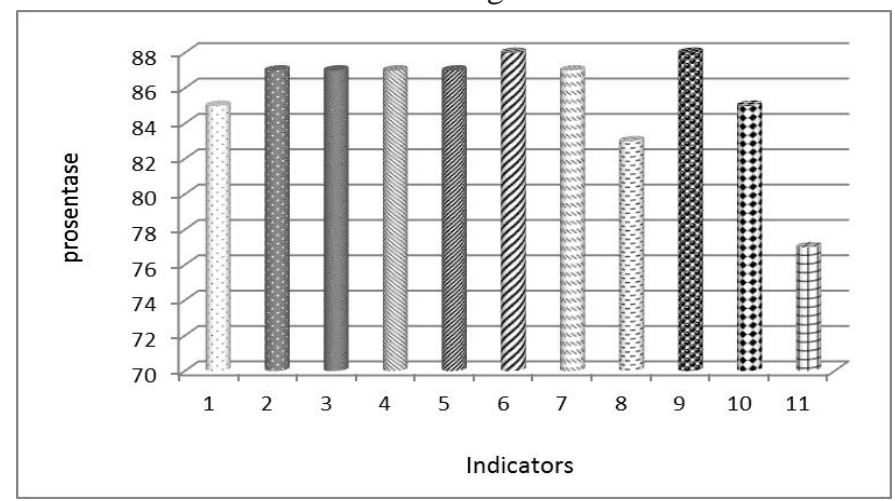

Fig 4. Management Education and Vocational Training

Figure 4 shows that the teachers' competence of providing improvement to the irregulation should be improved, so the education and training can be more attractive and accordance to the vision and mission of the education and training. The utilization of the training facilities and other media by training participants optimally should be enhanced. The training participant optimizes all of the training components in order to meet the training standard, so the training participant can acquire the training goals that had been planned. The optimalized training component by the training participant should be maintained.

Implementation for internal quality assurance in an activity refers to the principles of Plan, Do, Check, Action (PDCA). Iorganization education and training need to understand the internal quality and quality management system, so that training providers can make repairs before problems occur. The Components of Quality Control include several indicators, namely: (1) the teachers believe they can achieve the targets / objectives Training followed; (2) after following the training the teachers can implement the acquired materials; (3) The teachers give suggestion for the next training; (4) The teachers participate in providing advice on the effectiveness of 
the training programs implemented; (5) the teachers provide the information relating to the achievement of training objectives; (6) in following the Training, Teachers can identify the successes and failures in implementing Education and Training; (7) The teachers provide inputs to the standardization of the quality of the training; (8) the teachers give feedback to the quality objectives in the improvement of the Training; (9) after taking the training, they get a recommendation from the Teacher Training supervisor for the improvement of the quality of education; (10) teachers develop a minimal competency levels to achieve the competence of graduates; and (11) The teachers participates in the training to improve of their own quality. Ilustrates the percentage of component Quality Control shown in figure 5.

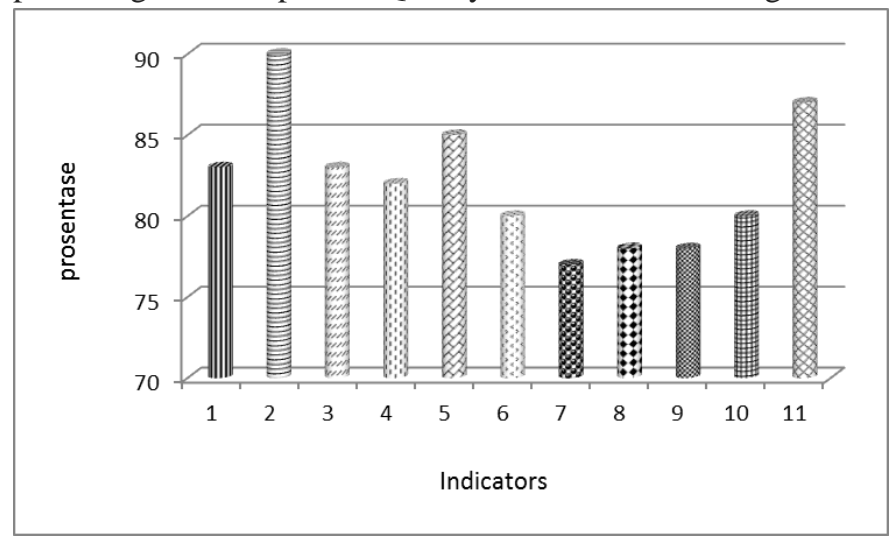

Fig. 5. Quality Control

Figure 5 shows that the indicators that should be improved are the competences of a teacher in providing the inputs to the standardization of the quality of education and training, so that the education and training can be more attractive and accordance with the vision and mission of education and training. Teacher give same sugestion for the quality of training objectives improvement. The teachers can implement the acquired materials, after attending the training. When the teacher return into the school they will improve and develop the teaching and learning process, so this indicator should be maintained.

Education and Training Agency through a quality assurance committee should establish, document, implement, maintain and improve continuously (continual improvement) the internal quality assurance in accordance with the requirements, guidelines and standards specified. In "improving sustainably" there are several instruments: (1) the teachers develop cognitive competencies / knowledge after the training; (2) the teachers develope the psychomotor competencies or skills after training; (3) the teachers develop the affective competencies of attitudes after training; (4) the teachers develop the indicators of the basic competency after training; (5) after carrying out the training, the teachers develop the students' level of competence; (6) after carrying out training, the Teachers develop the teaching methods; (7) the teachers develop learning materials to be more easily understood by students; (8) the teachers always develop the indicators of learning materials; (9) the teachers always inform the student achievement; and (10) the teachers develop the assessment criteria after training. Based on questionnaires results procentage of component Improving Sustainably shown in figure 6.

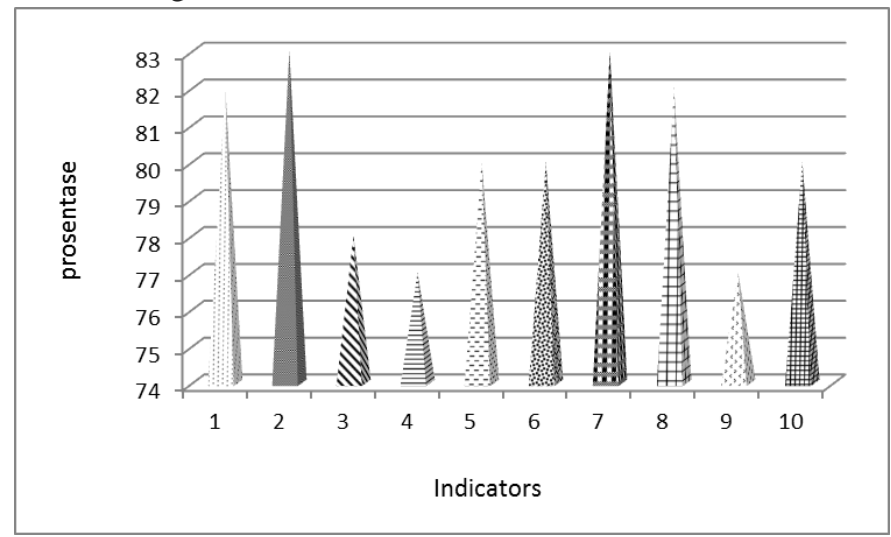

Fig. 6. Improving Sustainably

Figure 5 shows that the indicators that should be improved are the competences of a teacher develop the Indicators of the Basic competence after training so that the materials obtained by the students will be more concrete in accordance with the realities of lives. A teacher should always develop student competencies of knowledge, skills and attitudes. The Teachers develop the learning materials to be more easily understood by students, so that the students will be more fun and passion in taking the teaching competence maintained.

Components - supporting are required so that the education and training of vocational teachers can run effectively and efficiently, as seen in Figure 7. 


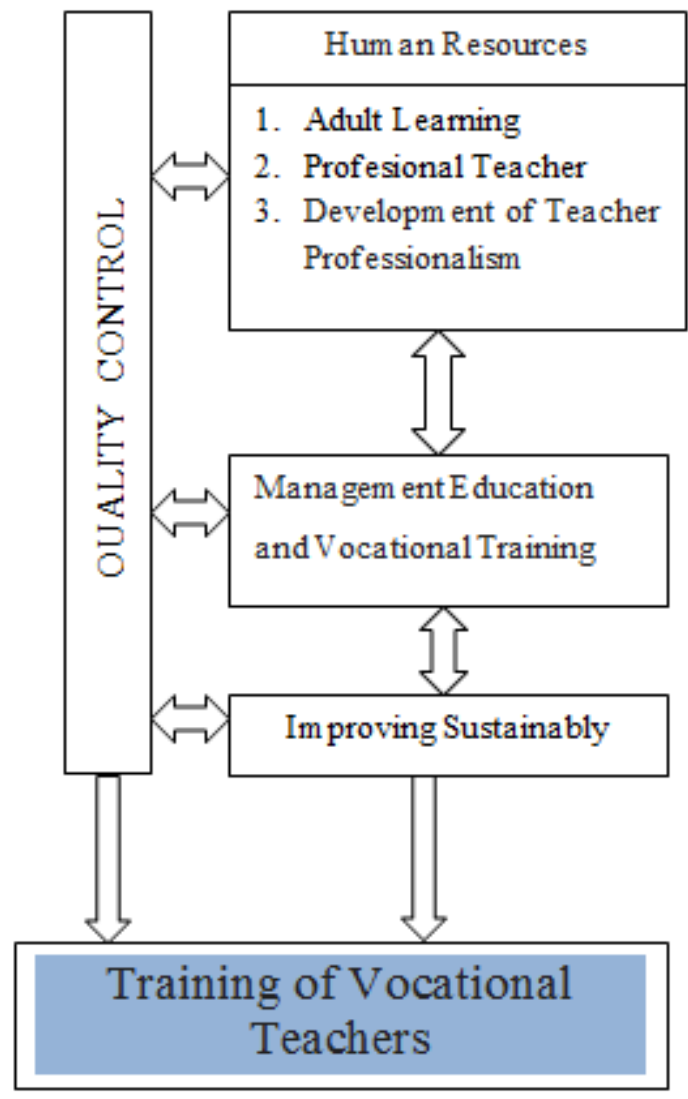

Fig 7. Components supporting education and learning

Quality Control vocational education and teacher training include human resources, management education and training and continuous improvement.

\section{IV.CONCLUSION}

The Management of Education and Training requires several components-supporting so that these activities can be achieved effectively and efficiently covering the Human Resources (adult learning, Professional Teacher, the development of the teacher professionalism), the Vocational Training Management and quality control. In order to guarantee the success of the training also requires the activities such as : Planning, organizing, actuating and Controlling
(PDCA). The Principle Application of PDCA in the Internal Quality Assurance System includes (1) Plan, plan what to do, (2) Do, the implementation of what is already planned or implementation of quality standards, (3) Check, the monitoring, inspection, measurement and evaluation of the implementation and results of the implementation of the quality standards including the execution control through Internal quality Audit, and (4) Action, the follow-up and the improvement of the quality standards of the evaluation results. The last component is that the teachers are always "Improving Sustainably."

\section{REFERENCES}

[1] G. Gabrhelová and L. Pasternáková, "Teachers in the Context of Vocational Education," Acta Technol. Dubnicae, vol. 6, no. 3, pp. 100$113,2016$.

[2] Shahadat Hossain Khan, "A model for integrating ICT into teacher training programs in Bangladesh based on TPCK," Int. J. Educ. Dev. Using Inf. Commun. Technol., vol. 10, no. 3, pp. 21-31, 2014.

[3] T. Bachkirova, "Dealing with issues of the self-concept and selfimprovement strategies in coaching and mentoring," Int. J. Evid. Based Coach. Mentor., vol. 2, no. 2, pp. 29-40, 2004.

[4] P. Runhaar, T. Bednall, K. Sanders, and H. Yang, "Promoting VET teachers' innovative behaviour: exploring the roles of task interdependence, learning goal orientation and occupational selfefficacy," J. Vocat. Educ. Train., vol. 68, no. 4, pp. 436-452, 2016.

[5] A. Chakraborty, "Importance of PDCA cycle for SMEs," SSRG Int. J. Mech. Eng., vol. 3, no. 5, pp. 30-34, 2016.

[6] P. Balqis, N. Usman, and S. Ibrahim, "Kompetensi Pedagogik Guru Dalam Meningkatkan Motivasi Belajar Siswa Pada SMPN 3 Ingin Jaya Kabupaten Aceh Besar," J. Adm. Pendidik. Pascasarj. Univ. Syiah Kuala, vol. 2, no. 1, pp. 25-38, 2014.

[7] S. Chan, "Applications of Andragogy in Multi-Disciplined Teaching and Learning," J. Adult Educ., vol. 39, no. 2, pp. 25-35, 2010.

[8] R. A. Darmenova, J. B. Ashirbekova, B. N. Otegenova, and B. L. Sh, "Professionalism Of The Teacher Of The Vocational Education As Condition Of Improvement Of Quality And Training Of Students," Int. J. Sci. Technol. Res., vol. 4, no. 4, pp. 17-20, 2015. 